\title{
6. CARDAMOM PRODUCTION IN KAVREPALANCHOWK
}

- Kiran Shrestha ${ }^{6}$

\begin{abstract}
Cardamom production is a potential cash crop of Kavre district. Many farmers were found to grow cardamom following traditional pattern. Women's participation in Cardamom production in Kavre is satisfactory and their roles are vital in the farm and market management. To check the status of cardamom production and women's role in Kavre, the researcher visited the District Agriculture Office and used snowball sampling technique to collect the primary data. For the secondary data, library method has been applied. Although the production and women's participation are highly encouraging, the farmers are reluctant to invest and produce cardamom at large scale. The study has found that the farmers need the entrepreneurship training, support and empowerment for mass production of cardamom. The future of cardamom production is bright in Kavre.
\end{abstract}

Key Words: Cardamom, Women participation in cardamom, cash crop.

\section{Introduction}

Large cardamom Anumum Sublemetum Roxb-Cardamom refers to several plants of the genera Elettaria and Amomum in the ginger family Zingiberaceae. It is mainly cultivated in the eastern hilly districts of Nepal as a cash crop. Around 70,000 farmers of eastern Nepal are involved in its production. cardamom was introduced into Nepal (Illam) in 1865, by Nepalese laborers who went to Sikkim for seasonal work. However, planned development of large cardamom was found to be started after establishment of Cardamom Development Centre at Fikkal, Ilam district in 1975. In the world, 16 cultivars of large cardamom are reported. Among them, only limited cultivar of large cardamom is cultivating in Nepal namely, Ramsai, Golsai, Chibesai, Dambersai, Sawney, and Kanti daar. Similarly, farmers are currently evaluating new cultivar known as Salkpure since three year in Ilam (GON, 2015). It is climate sensitive crop as it strictly requires cool, moist soil, humid under shaded area, range of 700- 2100 meter from above sea level for better performance. It is being commercially cultivated in more than 37 districts mainly in Ilam, Panchthar, Taplejung, Dhankuta, Terahthum Sankhuwasabha and Bhojpur districts and nearly 67,000 families are directly and indirectly involved in this farming.

Kavre:

Kavre district is culturally rich with historical places like Dhulikhel, Panauti, Banepa and Chandeni Mandan.Chandeni mandan is interesting place for tourism it cover the low and high point of the district, low point is Indrawoti river and highest point is Thamdanda (interesting place of hiking and 360 degree site viewing including top of the world) Big religious fairs like Chandeshwari Jatra of Banepa, Namobuddha Jatra of Namobuddha celebrated on the birth date of Lord Buddha (Buddha Purnima), Kumbha Mela of Panauti which happens once in 12 years, are

6 Mr. Shrestha is a PhD scholar and working as a lecturer at SV Academy Kathmandu. 
some interesting events to view. Kavre district has great potential in raising its local economy with tourism. Kavre has same potential as that of other tourist sites of Nepal like Pokhara and Jomsom. Kuseshwor Mahadev Daneshwor Mahadev, Banepa Chandeshworimata, Panauti Indrashwor Mahadev, Nala Bhagawati, Eklekkhet Dankali Devi, Sankhu Kalidevi, Timal Narayan Dham, Palanchowk Bhagawati, Panauti Kedhareshwor Mahadev, Khopasi Fadkeshwor Mahadev, Ladku Ladkeshwor Mahadev are the very famous places of Kavre.

The Long Himalayan Gaurishankar range can be seen from Dhulikhel. Kavre is famous for short circuit trekking in places like Dhungkharka-Narayanthan, Dhulikhel-Kavre-NamobuddhaSankhu-Panauti-Banepa. Some places to visit here in Kavrepalanchowk districts are: Palanchowk Bhagwati, Namobuddha, Dhulikhel, Gaukhureshwar, Hajar Sidhi (1000 Steps to Kali Devi Temple), Devisthan (where Kali Devi Temple is situated), Talu Dada View Tower, Gosainthan, Banepa, Khopasi, Pasthali, Balthali, Ladkeshwar Mahadev, Nepalthok, Patlekhet, Phulbari, Dapcha and many more.

Kavrepalanchowk is one of 77 districts of Nepal, near Kathmandu valley having the area of 1396 sq.ft., situated to mid-hilly area majorly having the subtropical climate and elevation range of 280 meters to 3018 meters (Bethanchok Narayan Danda). It is bordered to the east by Ramechhap and Dolakha, west by Kathmandu valley, north by Sindhupalchowk and south by Sindhuli and Makawanpur.

Effective technology transfer and higher adoption of developed technologies through multidimensional awareness and motivational participatory program will be necessary tool in large cardamom development among Nepalese farmers (Yadav, Shrestha, \& Mandal, 2015) According to those researchers' conclusion we need effective technology transfer in necessary for cardamom production. If we have mass production of large cardamom the socio cultural status of the people will be uplifted.

Researcher Sunita Yadav has mentioned in her conclusions that many forest related acts, rules and regulations like NBSIP (2006-2010), Forest Act 1993 and Regulation 1995, Herbs and NTFP Development policy 2004 have not specific provision for cardamom cultivation in Nepal. Therefore, national policies should develop policies for cardamom cultivation in Nepal. (Yadav S. , 2013) In regards to Ms Yadav there is the necessity of strong and effective Cardamom policy in order facilitates the cultivation and production of large cardamom.

Sony KC, Bishnu Raj Upreti and Bashu Prasad Subedi, have stated in their research on "We know the taste of sugar because of cardamom production": Links among Commercial Cardamom Farming, Women's Involvement in Production and the Feminization of Poverty additional research and analysis stemming out of the proceedings of this paper would be beneficial in framing and designing policies in the gender and commercial labor market sector, particularly for rural Nepal (KC, Uprety, \& Subedi, 2016). Shortcomings in Nepalese cardamom production are remaining for insufficient saplings supply; large ageing of shading plants, lack of research outputs and quality based improved dryers. Weaknesses are also seen in marketing and trade as lacking of Auction 
Market, ware house, suitable brandings, equipped quarantine laboratory as well as organized trading systems are importantly exist (Government of Nepal, 2015). Considering the conclusions of the above three researchers the society must be provided with trainings policies in order to uplift their social status.

Strong policies and strategies have to be formulated in order to strengthen the production of large cardamom, from the research perspective the research question of the study will be, what is the impact of cardamom production in the socio culture livelihood market of eastern Nepal?

A highly motivated farmer Upendra Timilsina, Rayale Lamidada, Panauti-1, in Kavrepalanchowk district said, "Farming cardamom was a new thing for me. I started it with seeds brought from Ilam district as everyone rated cardamom seeds of Ilam highly. But every time I planted them, they did not grow. It was very discouraging," he said, adding, "The failures accumulated loans, one after another. I once even contemplated committing suicide after being unable to repay the loans." (Guragain, 2017). Further District Agriculture Development Office (DADO), Kavre, later started helping the local farmers by providing them with technical help and skills development trainings. "Their help greatly aided in the production and marketing of cardamom plants. Farmers like us achieved more and more success after the help of DADO," said Timilsina.

He said that demands increased for cardamom's plant within and outside the district. After realizing the market prospects, Timilsina registered Fulchoki Multi-Purpose Model Nursery and started commercially producing its seeds and plants. He proudly shared that he is preparing 400,000 plants for sale this year. "Last year, my firm failed to meet the market demand. The demand for the plants is overwhelming this year as well." Likewise, Timilsina's brother, who has been in foreign employment since the past 18 years, has joined him in cardamom farming (Guragain, 2017). The cardamom plants produced by his firm are exported to Ramechhap, Dolakha, Sindhupalchowk, Dhading, Rukum, and many other districts of far western region. If cardamom plants get good fertilization, it bears fruit within 2-3 years, farmers said. "At present, demands for seeds is higher than plants. We have been sending seeds to as far as Ilam, Bhojpur, Taplejung and Sankhuwasabha among other districts. We have also formed groups with the villagers in order to meet the ever growing demand of our growing market," Timilsina informed (Guragain, 2017). This information evoked the researcher to conduct a study in Kavre district. Nepal has been well known from prehistoric times as the land of spices.

Spices are high value and low volume commodities of commerce in the world market. The estimated growth rate for spices demand in the world is around 3.19\% and in burgeoning trend (GON, 2015). There are 109 spices has been growing worldwide, 70 spices grown in Asia and more than 20 grown in Nepal. Among them it is high value potential endemic cash crop in mid hills of eastern development region of Nepal. Cardamom is lucrative and promising and viable agribusiness cash crops of the mid hills and main sources for the monetary requirement to the farmers. It is one of the important export leading agricultural commodities because of comparative advantage and competitive socio-economic aspect (GON, 2015). Nepal cardamom is evergreen 
vegetation agriculture commodity that promotes agro-ecotourism and build up pollution free and aesthetic environment to its periphery. It helps in soil conservation.

This industry attracts internal and external tourists that enhance long term economic growth and sustainable development. This commodity is socio-economically viable and ecologically versatile crop at national and local level. Although it is introduced during 1865 from India, its commercial cultivation only started from 1953 in Ilam district of Nepal. Thereafter, Cardamom Development Centre was established in Pandam, Ilam district during 1975 for extension of large cardamom growing areas.

\section{Methodology}

For this research the author had visited the Kavre district and visited the District Agriculture Development Office (DADO) situated in Dhulikhel for secondary data collections. Cardamom in Kavre is cultivated in Ryale Kushadevi - Bhumidanda presently in Panauti Municipality and also in Baluwapati, Nyaldum, Chalala Ganesthan, Gothaapani and Sano Banthali. About 150 farmers have cultivated Cardamom in 90 Hectors of land in 073/074 fiscal year, 81 metric ton of cardamom was grown in Kave District. .Ramsahi, Golsahi and Jirmale types are cultivated in Kavre. There are both primary and secondary cultivation of Cardamom in Kavre (DADO, 2018). Sampling was taken about $10 \%$ of the total populations of the cardamom farmers by visiting them. I have applied following methods for sampling The above data was obtained by personally interviewing the Extension Agriculture officer of DADO office Kavre Palanchowk district. Purposive Method and Snowball sampling methods were applied to collect the primary data and secondary data were collected from DADO Kavre and the statistical bureau of Nepal.

\section{Analysis and Discussion}

\section{Cardamom Production in Kavrepalanchowk}

\begin{tabular}{|l|l|l|l|l|l|l|}
\hline SN & Name of respondent & Land & Cultivation & $\begin{array}{l}\text { Product } \\
\text { 1st year }\end{array}$ & $\begin{array}{l}\text { Production } \\
\text { 2nd year }\end{array}$ & $\begin{array}{l}\text { Production } \\
\mathbf{3}^{\text {rd }} \text { year }\end{array}$ \\
\hline 1 & Upendra Timsina & 1 Ropani & 2061 & $40 \mathrm{~kg}$ & $90 \mathrm{~kg}$ & $120 \mathrm{~kg}$ \\
\hline 2 & Lok pd Accharya & 10 Ropani & 2064 & $100 \mathrm{~kg}$ & $150 \mathrm{~kg}$ & $200 \mathrm{~kg}$ \\
\hline 3 & Jureli sapkota & 2 Ropani & 2067 & $70 \mathrm{Kg}$ & $90 \mathrm{~kg}$ & $110 \mathrm{~kg}$ \\
\hline 4 & Ram Krishparajuli & 5 Ropani & 2061 & $40 \mathrm{~kg}$ & $80 \mathrm{~kg}$ & $95 \mathrm{~kg}$ \\
\hline 5 & Kamala Acharya & 1 Ropani & 2065 & $15 \mathrm{~kg}$ & $30 \mathrm{~kg}$ & $35 \mathrm{~kg}$ \\
\hline 6 & Sashi Adhikari & 3 Ropani & 2061 & $15 \mathrm{~kg}$ & $20 \mathrm{~kg}$ & $25 \mathrm{Kg}$ \\
\hline 7 & Gun Nath Sapkota & 3 Ropani & 2055 & $65 \mathrm{~kg}$ & $90 \mathrm{~kg}$ & $150 \mathrm{~kg}$ \\
\hline 8 & Surya bd Tamang & 1 Ropani & 2068 & $15 \mathrm{~kg}$ & $20 \mathrm{~kg}$ & $10 \mathrm{~kg}$ \\
\hline 9 & Narayan Pd sapkota & 1 Ropani & 2052 & $15 \mathrm{~kg}$ & $15 \mathrm{~kg}$ & $10 \mathrm{~kg}$ \\
\hline 10 & Bed Prasad sapkota & 1 Ropani & 2061 & $16 \mathrm{~kg}$ & $20 \mathrm{~kg}$ & $22 \mathrm{~kg}$ \\
\hline
\end{tabular}




\begin{tabular}{|l|l|l|l|l|l|l|}
\hline 11 & Dillip sapkota & 3 Ropani & 2062 & $15 \mathrm{~kg}$ & $22 \mathrm{~kg}$ & $5 \mathrm{~kg}$ \\
\hline 12 & Sabhu thapa & $\begin{array}{l}1.55 \\
\text { Ropani }\end{array}$ & 2067 & $30 \mathrm{~kg}$ & $40 \mathrm{~kg}$ & $50 \mathrm{~kg}$ \\
\hline 13 & Gyan Bd Thapa & 5 Ropani & 2068 & $40 \mathrm{~kg}$ & $50 \mathrm{~kg}$ & $60 \mathrm{~kg}$ \\
\hline 14 & Ram lila thapa & 3 Ropani & 2064 & $5 \mathrm{~kg}$ & $15 \mathrm{~kg}$ & $15 \mathrm{~kg}$ \\
\hline 15 & Dhana Thapa & 1Ropani & 2070 & $1 \mathrm{~kg}$ & - & - \\
\hline
\end{tabular}

(Source: Field Survey, 2018)

In Kavre, Agriculture Enterprises Center, a private sector under the Federation of Nepalese Chamber of Commerce and Industries, collects prices from different domestic markets and disseminates to the members providing market information. This institution advocates for the growth of large cardamom industry with government, encourages export promotion programs. It also helps to finalize the certificate of origin to needy. Presently, with the financial support of the TEPC, AEC constructs improved dryers in new cardamom production areas such as Kavre, Dolakha and Sindhuplachowk. Till now 300 improved dryers have been constructed in the other districts as Rolpa, Lamjung, Taplejung and Bhojpur (Government, 2015). NSCDP, a national level institution, is responsible for cardamom policy formation, implementing and supporting budgetary issues at respective districts. The aspect of technology transfers all over the cardamom growing districts comes through this organization operating under the Department of Agriculture. Policy and its implementing constraints, subsidies including national coordination aspects are also led by NSDP. With 50 percent of subsidies four improved dryers have been constructed in Kavre, Dolakha, Sindhupalchowk districts in current FY 2071/72 as well as 40 cardamom nurseries have been established within this same fiscal year (Government, 2015).

Natives of Mountains of South west India is known as the Cardamom Hills (Naeir, 1983). Cardamom was used by Hindus in ceremonies to pay respect to the recently deceased. Ancient Indians, more than 1,000 years before Christ, used cardamom medicinally to treat various maladies (KC, Uprety, \& Subedi, 2016). It is believed that the West got its first taste of cardamom when Alexander the Great brought it back from India. It was used widely in Europe to treat digestive problems (Subba \& Ghosh, 2017). Because this herb is considered an aphrodisiac, Culpeper assigned it to Venus. But it is all Mars--warming and stimulating. Often described as sweet and having "grateful warmth". It is frequently found in love charms (or perhaps better to say lust charms), but as a Mars herb, it can be equally effective in magical protection. It is a stimulant to the mind and warming to the body, said to uplift the spirits, calm the nerves, and help clarify thinking. It was known in 4 century BC to the Latin. The Lepchas were first to collect the leaves of cardamom for medicinal herbs and later developed farming (Yadav, Shrestha, \& Mandal, 2015). Thus from the discussion of the data shown in table the potentiality of cardamom production in Kavre is very high although the farmers are not very much motivated on this cash crop. 


\section{Roles of Women in Cardamom Production in Kavre}

The overall literacy rate is $51 \%$ for women and $72 \%$ for men, and this gender difference in literacy is more pronounced in rural areas. This lack of knowledge lowers self-confidence and affects other activities in the value chain in that women are unable to bargain for better quality inputs or practice professional farming, for example (Govt. of Nepal, 2015). Women's businesses tend to be small and thus subject to high volatility and unable to leverage credit to grow the business. Even though both men and women equally work in this sector, women tend to do more value addition work such as cleaning, cutting and grading of cardamom, while men tend to be the ones to bring the finished product to the market.

Customary norms on women's role in households and public life, which often show bias in favor of men, limit their ability to make decisions, seize opportunities and get access to productive resources (International Trade Centre -ITC, 2017). In fact, due to the legal and sociocultural norms in Nepal, women experience poverty and inequality to a greater degree. They are often excluded from formal processes and structures and lack access to market information technologies and productive inputs.

In addition to this, not all women's tasks are economically productive; rural women play roles such as caretakers of family and unpaid family workers (International Trade Centre -ITC, 2017). As their tasks are usually more tedious and time-consuming, this leads to time poverty and lost opportunities for women in attending trainings and invest in income-generating activities. In Nepal's agricultural sector, around $90 \%$ of the farmers are women and most are usually small farm operators (International Trade Centre -ITC, 2017). Both men and women have been reported to be equally engaged in cardamom farming, in preparing the farm, planting the saplings, weeding, irrigating or watering, harvesting or picking the capsules, drying the cardamom and selling the product.

However, women also perform value addition tasks which include cleaning, cutting and grading of large cardamom. It is mostly women who work in processing centers that carry out the value addition Tail cutting and cleaning: Tail cutting is a tedious process, done using simple scissors, it is carried out by women who are paid by the volume/weight that they process. Cleaning is done by both women and men. work, while it is mostly men who take the cardamom to Women in the large cardamom sector face low wages and repetitive, labor intensive tasks, especially at the processing stage (International Trade Centre -ITC, 2017). It is seen from the above table that there is considerable no of women resource used in the cardamom farming in Panauti. After the massive earthquake that took place in 2015 that vandalized more than 1000 houses in Kavreplanchowk male members of the district have been engaged in the remuneration project. Literacy rate of cardamom producers is greater than the local people. The above data obtained from the local cardamom cultivators' reveals that their off springs have admitted in the school and universities situated in nearby cities as Dhulikhel Panauti and Banepa and Kathmandu and some are professional degree holders as pilot and doctors. 
The status of women in cardamom production is not different than other agriculture. Almost all the activities are conducted by women but name goes to her man. women's participation is satisfactory however wages are lower.

\section{Conclusions}

The potentiality of cardamom production in Kavrepalanchowk is very high but the farmers are not very much motivated on this cash crop. The status of women in cardamom production is not different than other agriculture activities. Almost all the activities are conducted by women but names go to their men. women's participation is satisfactory however wages are lower. It is recommended that Kavre is a most potential district for Cardamom cultivation where the locals should invest more on research and development of farmer and cultivation process.

\section{References}

DADO, O. (2018, March 2). ADO. (K. Shrestha, Interviewer)

Government Of Nepal. (2015). Trade Flow Analysis of Large Cardamom in Eastern Nepal. Kathmandu: Ministry of Agricultural Development, Agribusiness Promotion and Statistics Division International Trade Promotion Section.

Government of Nepal. (2015). Trade Flow Analysis of Large Cardamom in Eastern Nepal. Kathmandu: Ministry of Agricultural Development, Agribusiness Promotion and Statistics Division International Trade Promotion Section.

Government of Nepal. (2015). Trade Flow Analysis of Large Cardamom in Eastern Region. Kathmandu: Ministry of Agricultural Development, Agribusiness Promotion and Statistics Division, International Trade Promotion Section .

Guragain, G. (2017, June 12). Cardamom Framing: a success story from Kavre. My Republica, p. 2 .

International Trade Centre -ITC. (2017). Nepal National Sector Export Strategy LargeCardamom 2017- 2021. Kathmanu: Government of Nepal.

KC, S., Uprety, B. R., \& Subedi, B. P. (2016). "We know the taste of sugar because of cardamom production"Links among Commercial Cardamom Farming, Women's Involvement in Production and the Feminization of Povertylthe Feminization of Poverty1. Journal of International Women's Studies, 202.

Naeir, G. (1983). Marketing of Cardamom.

Subba, S., \& Ghosh, S. (2017). Status of Large Cardamom (Amomum subulatum)among the Major Crops in Sikkim, India. International Journal of Current Microbiology and Applied Sciences, 2017 1-2. 
Yadav, P. K., Shrestha, K. P., \& Mandal, D. L. (2015). Present Situation and Future Strategies for Research and Development of Large Cardamom in Nepal. Proceedings of the Stakeholders Consultation Workshop on Large Cardamom Development in Nepal, 2015 1-8.

Yadav, S. (2013). Cardamom cultivation and its effect in rural livelihood and its importance in international market. MSC Thesis, 65 . 